\title{
STUDI PENGEMBANGAN PERANGKAT PEMBELAJARAN (BAHAN AJAR) DI MTS AL-KHAIRAT KOTA TERNATE
}

\author{
Dahlan Usia ${ }^{1}$ dan Jainudin Abdullah ${ }^{2}$ \\ ${ }^{1}$ Alumni Prodi Pendidikan Pancasila dan Kewarganegaraan, FKIP Universitas Khairun, Jl. Bandara Baabullah Akehuda \\ Ternate Utara, 97728, Indonesia \\ ${ }^{2}$ Dosen Prodi Pendidikan Pancasila dan Kewarganegaraan, FKIP Universitas Khairun, Jl. Bandara Baabullah Akehuda Ternate \\ Utara, 97728, Indonesia
}

Author Correspondence: dahlan_usia@yahoo.com

$\begin{array}{ll}\text { Diterima } & : 20-03-2018 . \\ \text { Direvisi } & : 30-03-2018 \\ \text { Dipublikasi } & : 05-04-2018\end{array}$

Abstract. The development of learning devices and teaching materials is essentially the development of short-term learning tools to estimate or project what will be done in learning activities. The development of learning tools and teaching materials are translated from syllabus or RPP to direct students' learning activities in an effort to achieve Basic Competency. This research is descriptive qualitative researchers with data collection techniques, namely: (1). Observation Technique; (2). Interview technique; and (3). Documentation techniques. As for the purpose of this study to find out the development of learning devices and teaching materials at MTs Al-Khairat. Kota Ternate and to find out the factors that influence the development of learning devices and teaching materials. The results of this study indicate that the development of learning devices and teaching materials at MTs Al-Khairat. Kota Ternate are as follows: (1). learning devices and teaching materials at MTs Al-Khairat Kota Ternate in using educational unit level curriculum. But in the study of compost and its substance there are some teachers who have not understood substantially. Without formulation and indicators that have been set in the development of learning devices; and (2) In the development of learning devices and teaching materials at MTs Al-Khairat. Kota Ternate begins with an analysis of subject matter in accordance with standards and compotency expected in the formulation of the development of learning tools namely (RPP) and syllabus, where teachers are still experiencing difficulties. This is due to the lack of involvement of teachers in developing their competence or training in developing teaching materials / learning devices.

Keywords: Development, Teaching Materials, MTs Al-Khairat Kota Ternate

\section{PENDAHULUAN}

Proses belajar yang tidak tepat menjadi indikator utama bagi siswa yang kita ajarkan, karena siswa tidak menerima pelajaran Bahkan, siswa akan melakukan perbuatan iseng yang mengganggu proses belajar karena siswa tidak mempunyai etika, norma maka tidak bisa menghargai gurunya sendiri. Bahkan bisa berakibat menurunnya rasa hormat siswa kepada gurunya. Karena menjadi kendala dalam mengelola pembelajaran adalah strategi dan metode mengajar yang digunakan kurang tepat. Dalam hal ini, diartikan bahwa strategi dan metode yang digunakan guru tidak sesuai dengan materi pelajaran atau kondisi siswa. Akibatnya, pengelolaan kelas dalam pembelajaran akan terganggu. Perilaku siswa yang menyimpang sangat mudah berawal dari strategi dan metode mengajar yang kurang tepat. Siswa merasa pembelajaran yang sedang berlangsung tidak ada manfaatnya karena tidak bisa diterima dengan baik.

Proses pembelajaran berlangsung dalam suasana tertentu yakni situasi belajar mengajar. Dalam situasi ini, terdapat faktor-faktor yang saling berhubungan yaitu: tujuan pembelajaran, siswa yang belajar, guru yang mengajar, bahan yang diajarkan, metode pembelajaran, alat bantu mengajar, prosedur penilaian, dan situasi pengajaran. Dalam proses pengajaran tersebut, semua faktor bergerak secara dinamis dalam suatu rangkaian yang terarah dalam rangka membawa para siswa/peserta didik untuk mencapai tujuan pengajaran. Pengajaran merupakan suatu pola yang didalamnya tersusun suatu 
prosedur yang direncanakan dan terarah serta bertujuan. Memang secara umum ada langkahlangkah pelaksanaan pembelajaran yang umum dalam pembelajaran apapun untuk siapapun dan kapanpun. Guru membuka pelajaran, menjelaskan materi, murid menyimak kalau perlu bertanya, mengevaluasi dan menutup pelajaran.

Pendidikan adalah usaha sadar dan terencana untuk mewujudkan suasan belajar dan proses pembelajaran agar peserta didik secara aktif mengembangkan potensi dirinya untuk memiliki kekuatan spritual keagamaan, pengendalian diri, kepribadian, kecerdasan, akhlak mulia, serta keterampilan yang diperlukan dirinya, masyarakat, bangsa dan negara. Sistem pendidikan nasional adalah keseluruhan komponen pendidikan yang saling terkait secara terpadu untuk mencapai tujuan pendidikan nasional. Pendidikan nasional adalah pendidikan yang berdasarkan pancasila dan Undang-Undang Dasar Negara Republik Indonesia Tahun 1945 yang berakar pada nilai-nilai, kebudayaan nasional Indonesia dan tanggap terhadap tuntutan zaman (Sisdiknas, 2003).

Pembelajaran dapat diartikan sebagai jalan yang digunakan oleh guru pembelajar untuk menciptakan suasana yang memungkinkan siswa belajar. Dalam pembelajaran Kurikulum Tingkat Satuan Pendidikan yang telah diberlakukan sekarang ini, pendidik terutama guru Pendidikan Kewarganegaraan dituntut untuk selalu kreatif dalam membuat dan menyusun silabus yang sesuai kondisi dan minat siswa. Selain itu guru juga harus inovatif dalam membuat media pembelajaran yang cocok untuk menjelaskan materi Pendidikan Kewarganegaraan. Karena terkadang perlu penjelasan yang lebih untuk memahami konsep dasarnya, sehingga materi tersebut mudah dipahami dan dimengerti oleh siswa maka guru harus menerangkan dengan menggunakan metode-metode yang di pahami oleh guru mata pelajaran agar mudah di pahami siswa tentang apa yang di ajarkan.

Salah satu tindakan guru yang utama adalah menyelenggarakan pelaksanaan proses belajar mengajar atau proses pembelajaran. Proses pembelajaran merupakan serangkaian kegiatan antara guru dan siswa atas dasar hubungan timbal balik yang berlangsung dalam situasi edukatif untuk mencapai tujuan tertentu. Hubungan timbal balik antara guru dan siswa tersebut merupakan syarat utama dalam pelaksanaan proses pembelajaran. Interaksi dalam proses pembelajaran mengandung makna yang lebih luas daripada sekedar hubungan antara guru dan siswa, sebab di dalamnya terkandung makna interaksi edukatif, yang tidak hanya berupa penyampaian pesan atau materi pelajaran. Proses pembelajaran mengandung makna lebih luas daripada proses mengajar. Dalam proses pembelajaran tersirat adanya suatu kesatuan kegiatan yang tak terpisahkan antara siswa dan guru, dimana antara keduanya terjalin hubungan yang saling menunjang.

Dengan alasan yang telah dijabarkan di atas peneliti akan mengadakan penelitian secara deskiptif kualitatif. Sehingga penulis mengharapkan dalam penelitian ini terdapat perubahan-perubahan dalam pelaksanaan pembelajaran sesuai dengan tuntuan pendidikan. Oleh karena itu pertanyaan yang diajukan dalam tulisan ini adalah bagaimana pengembangan perangkat pembelajaran (bahan ajar) di MTs Al-Khairat Kota Ternate dan kendala-kendala apa saja yang di jumpai oleh guru-guru MTs Al-Khairat dan pengembangan perangkat pembelajaran (bahan ajar) .

\section{METODE PENELITIAN}

Penelitian ini menggunakan metode kualitatif deskritif, pada dasarnya merupakan suatu proses penyelidikan (Maleong, 2007: 32). Dari sebuah penyelidikan yang menghimpun data-data utama sekaligus data tambahan. Penelitian menggunakan metode kualitatif ini adalah lebih tepat untuk mengidentifikasi permasalahan yang terkait dengan pengembangan perangkat pembelajaran (bahan ajar) di MTs Al-Khairat Kota Ternate. Penelitian ini dilaksanakan di lokasi tersebut dipilih karena mudah dijangkau oleh peneliti sehingga mempermudah peneliti untuk memperoleh data. Selanjutnya penelitian ini dilaksanakan selama 1 bulan sejak tanggal 26 Maret sampai 28 April 2017. Dalam penelitian ini yang menjadi subjek penelitian ini adalah kepala sekolah, dan wakil kepala sekolah bidang kurikulum. 


\section{Teknik Pengumpulan dan Analisis Data}

Teknik pengumpulan data dalam penelitian ini melalui, observasi, wawancara dan dokumentasi. Teknik obsevasi merupakan metode mengumpulkan data dengan mengamati langsung di lapangan, proses ini berlangsung dengan pengamatan yang meliputi melihat, merekam, menghitung, mengukur, dan mencatat kejadian. Observasi biasa dikatakan merupakan kegiatan yang meliputi pencatatan secara sistematik kejadian-kejadian, perilaku, objek-objek yang dilihat dan hal-hal lain yang diperlukan dalam mendukung penelitian yang sedang dilakukan (Rahmawatinadya, 2011); (2) Teknik Wawancara. Sutrisno Hadi (1981: 36), mengatakan bahwa wawancara adalah sebagai suatu proses tanya jawab secara lisan dua orang atau lebih berhadapan fisik, yang satu dapat melihat muka yang lain mendengarkan dengan telinganya sendiri dan suaranya, tanpa menggunakan alat informasi yang langsung tentang beberapa jenis data sosial. Metode ini penulis gunakan untuk memperoleh data yang sesuai dengan tujuan penelitian. Dalam hal ini yang menjadi informan adalah Kepala Sekolah dan wakil kepala sekolah bidang kurikulum; (3) Teknik Dokumentasi. Dokumentasi merupakan cara memperoleh dengan mempelajari, mencatat atau membuat salinan dari dokumen dan arsip yang berhubungan dengan objek atau permasalahan penelitian (Arikunto, 2006: 51).

Penelitian ini menggunakan teknik analisis data kualitatif yakni data-data yang diperoleh dari berbagai literatur, pengamatan atau observasi secara langsung di lokasi penelitian, wawancara dengan informen, yakni kepala sekolah dan wakil kepala sekolah bidang kurikulum serta dokumentasi berupa gambar-gambar yang di buat oleh peneliti saat melakukan penelitian untuk dideskripsikan secara kualitatif sehingga dapat menguraikan hasil penelitian serta menarik kesimpulan. Setelah data diperoleh dari melalui Observasi, wawancara, dan Studi Dokumentasi, data tersebut di analisis secara kualitatif (Sutrisno Hadi, 1981: 57). Analisis data merupakan upaya mencari, menata secara sistematis pemahaman peneliti tentang kasus yang diteliti dan menyajikannya sebagai temuan bagi orang lain (Maleong, 2007: 28).

\section{HASIL DAN PEMBAHASAN}

\section{Prinsip-Prinsip Pembelajaran dan Pengembangan Perangkat Pembelajaran}

Dari hasil pengamatan dan wawancara dengan Kepala Sekolah bahwa pembelajaran pada hakikatnya merupakan suatu bentuk interaksi antara peserta didik dengan lingkungan belajar guna tercapainya tujuan pembelajaran. Terdapat beberapa prinsip umum yang harus diperhatikan baik oleh pengajar maupun peserta didik agar pembelajaran bisa terlaksana dengan efektif serta mencapai tujuan yang diharapkan. Sejalan dengan itu, Alwasilah dalam Arifin (2009: 5) mengemukakan beberapa prinsip umum dalam pembelajaran sebagai berikut; (1) Bahwa belajar menghasilkan perubahan perilaku peserta didik yang relatif permanen; (2) Peserta didik memiliki potensi, gandrung dan kemampuan yang merupakan benih kodrati untuk ditumbuhkembangkan; (3) Perubahan atau pencapaian kualitas ideal itu tidak tumbuh alami linier sejalan proses kehidupan.

Selain prinsip-prinsip umum di atas, terdapat juga prinsip-prinsip khusus dalam pembelajaran. Prinsip-prinsip tersebut mencakup terhadap hal-hal spesifik yang harus dihadirkan dalam sebuah kegiatan pembelajaran guna berlangsungnya suatu kegiatan pembelajaran efektif. Berikut adalah prinsip-prinsip khusus dalam pembelajaran seperti yang dikemukakan oleh Alwasilah dalam Arifin (2009: 164):

\section{Prinsip Perhatian dan Motivasi}

Perhatian merupakan salah satu prinsip yang paling penting dalam suatu kegiatan pembelajaran. Gage dan Berliner dalam Sukirman (2010: 5) mengungkapkan bahwa "Tanpa adanya perhatian tidak mungkin akan terjadi suatu proses belajar pada diri siswa." Seorang pengajar harus mampu menciptakan perhatian pada diri peserta didiknya, baik itu perhatian pada pengajar itu sendiri ataupun perhatian kepada materi yang sedang diajarkan. Perhatian berfungsi sebagai modal awal yang harus dikembangkan secara optimal untuk memperoleh proses dan hasil pembelajaran yang maksimal. 


\section{Prinsip Keaktifan}

Suatu kegiatan pembelajaran yang baik pada dasarnya harus terjadi atas dorongan motivasi internal dari diri seorang peserta didik. Agar pembelajaran dapat mencapai hasil yang optimal, seorang peserta didik harus memiliki kesadaran untuk mau mempelajari serta memahami ilmu yang diajarkan. Sebuah kegiatan pembelajaran tidaklah dapat terjadi atas dorongan/paksaan orang lain. Walaupun terjadi seperti itu, peserta didik akan mempelajari materinya secara malas-malasan hingga timbul kesadaran pada dirinya sendiri bahwa ia memang ingin dan membutuhkan materi pelajaran tersebut. Hal tersebut sesuai dengan yang dikemukakan oleh Dewey dalam Arifin (2011: 166) yang mengemukakan, "belajar menyangkut apa yang harus dikerjakan siswa oleh dirinya sendiri, maka inisiatif belajar harus muncul dari dirinya." Menyikapi pendapat Dewey tersebut, seorang pengajar di dalam kelas harus berusaha sebisa mungkin untuk menerapkan prinsip keaktifan dalam diri peserta didiknya. Pembelajaran diupayakan untuk selalu berpusat pada diri peserta didik (student-centered learning) serta mengakomodasi potensi individu setiap peserta didik dalam suatu kegiatan pembelajaran yang kondusif. Peserta didik sebagai subyek belajar harus diarahkan untuk memiliki sifat aktif, konstruktif dan mampu merencanakan, mencari, mengolah informasi, menganalisis, mengidentifikasi, memecahkan, menyimpulkan dan melakukan transformasi (transfer of learning) ke dalam kehidupan yang lebih luas.

\section{Prinsip Keterlibatan Langsung/Berpengalaman}

Belajar bukanlah sekedar proses menghapal sejumlah konsep, prinsip atau fakta yang siap untuk diingat, melainkan sebuah proses yang benar-benar melibatkan diri peserta didik untuk masuk dan memahami materi pembelajaran serta dapat menerapkannya dalam kehidupan sehari-hari. Pendekatan pembelajaran yang mampu melibatkan siswa secara langsung akan menghasilkan pembelajaran yang lebih efektif sehingga dapat mencapai tujuan pembelajaran yang telah ditetapkan secara lebih optimal. Pendekatan pembelajaran seperti ini akan memberikan hasil yang lebih efektif dibandingkan dengan pendekatan yang hanya sekedar menuangkan pengetahuan, fakta atau informasi saja.

\section{Prinsip Pengulangan}

Pentingnya keberadaan prinsip pengulangan dalam sebuah kegiatan pembelajaran bisa merujuk kepada teori Psikologi Daya. Seperti dikemukakan oleh Arifin (2011: 167) bahwa, "menurut teori daya, manusia memiliki sejumlah daya seperti mengamati, menanggapi, mengingat, mengkhayal, merasakan, berpikir dan sebagai berikut. Setiap daya tersebut harus berkembang serta berubah menjadi lebih peka. Untuk mencapainya, diperlukan kegiatan pembelajaran dengan pengulangan.”

\section{Prinsip Tantangan}

Salah satu komponen dalam sistem pembelajaran adalah tujuan pembelajaran. Tujuan pembelajaran ialah target yang harus bisa dicapai oleh peserta didik di akhir suatu kegiatan pembelajaran. Dalam perjalanan untuk mencapai tujuan tersebut, peserta didik dihadapkan pada sejumlah hambatan/tantangan untuk memahami isi dari materi yang diajarkan. Di sini, akan timbul motif pada diri peserta didik untuk menuntaskan hambatan/tantangan tersebut dengan cara mempelajari bahan-bahan pembelajaran yang berhubungan. Dalam mencapai tujuan pembelajaran, siswa ditantang untuk mencari dan menemukan konsep-konsep, prinsip-prinsip serta generalisasi dari ilmu pengetahuan yang sedang dipelajari.

\section{Prinsip Balikan dan Penguatan Dasar}

Dari prinsip balikan dan penguatan pada pembelajaran ini adalah Law of Effect dari Thorndike. Hukum tersebut menyatakan bahwa peserta didik akan belajar dengan lebih semangat apabila mengetahui dan mendapatkan hasil belajar yang baik. Apalagi hasil yang baik merupakan balikan yang menyenangkan dan berpengaruh baik bagi usaha belajar selanjutnya. Selain hasil yang baik, BF Skinner menyatakan bahwa penguatan negatif/yang tidak menyenangkan pun bisa menjadi suatu 
dorongan belajar bagi peserta didik. Dalam menerapkan prinsip ini, seorang pengajarnbisa mengimplementasikannya dengan memberikan balikan/penguatan setelah mendapat respon pembelajaran dari seorang peserta didik. Respon tersebut tidak hanya diberikan di akhir pembelajaran berupa nilai/peringkat, tapi bisa diberikan juga segera setelah peserta didik melakukan aktivitas pembelajaran. Misalnya memberikan pujian/koreksi setelah seorang peserta didik memberikan pendapatnya terhadap suatu materi, atau berdiskusi dengan peserta didik tentang suatu materi pelajaran. Hal-hal seperti ini akan membuat peserta didik terdorong untuk belajar dengan lebih giat dan bersemangat.

\section{Prinsip Perbedaan Individu}

Setiap peserta didik di kelas pada hakikatnya memiliki perbedaan individu masing-masing, baik dari segi kelemahan maupun keunggulan, atau dalam segi fisik maupun psikis. Hal ini akan berdampak pada perbedaan kemampuan tiap individu tersebut dalam menyerap materi pelajaran. Seorang pengajar yang baik harus dapat mengenali perbedaan di setiap individu peserta didiknya supaya dapat memberikan perlakuan dan pelayanan pendidikan yang sesuai dengan kemampuan dan kebutuhan masing-masing peserta didik. Ciri dan karakteristik yang berbeda dari setiap individu peserta didik tersebut penting untuk dapat dikenali dan dipahami supaya seorang pengajar bisa menyiapkan dan menyajikan pelajaran, memberikan tugas, serta memberikan bimbingan yang sesuai kepada masing-masing peserta didik.

\section{Pengembangan Bahan Ajar di MTs Al-Khairat Kota Ternate}

Dari hasil pengamatan dan wawancara dengan Wakil Kepala Sekolah bidang Kurikulum bahwa Perangkat pembelajaran adalah sejumlah bahan, alat, media, petunjuk dan pedoman yang akan digunakan dalam proses pembelajaran." Dari uraian tersebut dapatlah dikemukakan bahwa perangkat pembelajaran adalah sekumpulan media atau sarana yang digunakan oleh guru dan siswa dalam proses pembelajaran di kelas, serangkaian perangkat pembelajaran yang harus dipersiapkan seorang guru dalam menghadapi pembelajaran di kelas, berikut dalam tulisan ini kami membatasi perangkat pembelajaran hanya pada: (a) Rencana pelaksanaan Pembelajaran (RPP), Buku siswa (BS), Buku Pegangan Guru (BPG), Lembar Kegiatan Siswa (LKS), dan Tes Hasil Belajar.

Berdasarkan hasil observasi di MTs Negeri Kota Ternate, dapat ditemukan pengembangan bahan ajar sebagaimana dipaparkan masing-masing perangkat pembelajaran sebagai berikut.

\section{Rencana Pelaksanaan Pembelajaran (RPP)}

Rencana pelaksanaan pembelajaran merupakan panduan kegiatan guru dalam kegiatan pembelajaran sekaligus uraian kegiatan siswa yang berhubungan dengan kegiatan guru yang dimaksudkan. RPP ini disusun berdasarkan indikator-indikator yang telah disusun mengacu pada prinsip dan karakteristik pembelajaran yang dipilih berisi tujuan pembelajaran, materi ajar, metode pengajaran, sumber belajar, dan penilaian hasil belajar, RPP yang disusun mencakup alokasi waktu 2x 40 menit (khusus SMP) untuk setiap pertemuan (tatap muka).

Berkaitan dengan rencana pelaksanaan pembelajaran (RPP), lebih lanjut O'Meara (2000) menyarankan agar dapat digunakan secara praktis oleh guru dan dapat dengan mudah diobservasi. Rencana pelaksanaan Pembelajaran (RPP) memuat tujuan isi atau materi pembelajaran, metode pembelajaran, kegiatan pembelajaran, daftar pustaka dan penilaian. Rencana pelaksanaan pembelajaran disusun dengan baik, terurut dan didesain dengan baik.

\section{Buku}

Buku sebagai rangkaian dari perangkat pembelajaran tentunya haru memberikan manfaat bagi guru khususnya siswa. Depdiknas (2008a:12) menjelaskan bahwa "Buku adalah bahan tertulis yang menyajikan ilmu pengetahuan buah pikiran dari pengarangnya." Lebih lanjut dijelaskan dari sumber yang sama (Depdiknas, 2008a:12), bahwa: Buku sebagai bahan tertulis merupakan buku yang berisi suatu ilmu pengetahuan hasil analisis terhadap kurikulum dalam bentuk tertulis. Sedangkan buku yang baik adalah buku yang ditulis dengan menggunakan bahasa yang baik dan mudah dimengerti, 
disajikan secara menarik dilengkapi dengan gambar dan keterangan-keterangannya, isi buku juga menggambarkan sesuatu yang sesuai dengan ide penulisnya. Selain penjelasan tersebut, dalam bagian yang sama, dijelaskan bahwa "Buku pelajaran berisi ilmu pengetahuan yang dapat digunakan oleh peserta didik untuk belajar (Depdiknas, 2008a:12).

Sumber lain tentang buku adalah Permendiknas RI No. 2 tahun 2008 Tentang buku panduan pendidik dijelaskan dalam Bab I, pasal 1, butir 4, bahwa "Buku panduan pendidik adalah buku yang memuat prinsip, prosedur, deskripsi materi pokok, dan model pembelajaran untuk digunakan oleh para pendidik" (Depdiknas, 2008b:2). Beberapa batasan buku di atas menjelaskan bahwa buku sebagai salah satu bahan ajar jenis bahan cetak merupakan buku yang substansinya adalah pengetahuan, yang disusun berdasarkan analisis kurikulum, disusun untuk memudahkan guru dalam pembelajaran dan siswa belajar mencapai kompetensi yang ditetapkan kurikulum, dengan memperhatikan kebahasaan, kemenarikan, dan mencerminkan ide penulisnya.

\section{KESIMPULAN}

Berdasarkan hasil penelitian yang berkaitan dengan pengembangan perangkat pembelajaran (bahan ajar) di MTs Al-Khairat Kota Ternate; (1) Pengembangan perangkat pembelajaran (bahan ajar) di MTs Al-Khairat Kota Ternate, pada proses pelaksanaan pembelajaran guru yang telah menggunakan perangkat pembelajaran dan bahan ajar yaitu RPP, Silabus dan fasilitas lainnya agar pada proses pembelajaran tidak mendapat kendala-kendala di kelas saat proses pelaksanaan pembelajara berlangsung baik guru maupun siswa sehingga bahan ajar yang digunakan guru siswa dapat menerima materi yang diajarkan dengan baik; (2) Dalam pelaksanaan pembelajaran, kendala-kendala yang ditemukan para guru sewaktu proses pelaksanaan pembelajaran disebabkan karena masih minimnya keterlibatan guru yang kurang mengikuti kegiatan-kegiatan peningkatan kapasitas guru dalam mengembangkan kompetensinya pada mata pelajaran yang diajarkan; (3) Para guru selalu mengembangkan perangkat pembelajaran (bahan ajar) dalam proses pembelajaran peserta didik bisa aktif menerima materi yang diajarkan oleh guru dan mempermudah bagi peserta didik untuk menemukan jawaban yang disodorkan dan mampu menyampaikan pendapatnya; (4) Para guru mengajar selalu teratur dan menggunakan media pembelajar harus sesuai sehingga tidak berpengaruh bagi guru maupun peserta didik dalam proses pembelajaran.

\section{DAFTAR PUSTAKA}

Suryosubroto, B. (2009). Proses Belajar Mengajar di Sekolah, Jakarta: PT Rineka Cipta

Bobi, D., Mike, H. (2000). Quantum Learning Membiasakan Belajar Nyaman dan Menyenangkan. Bandung: Kaifa.

Depdiknas (2005). Peraturan Pemerintah no. 19 tahun 2005 tentang Satandar Nasional Pendidikan. Jakarta: depdiknas.

Depdiknas, Dirjen Dikdasmen. (2003). Pendekatan Kontekstual (Contekstual Teaching and Learning-CTL). Jakarta : Direktorat Pendidikan Lanjutan Pertama.

Gordon, D \& Jeannette, V. (2000). Revolusi Cara Belajar (The Learning Revolution), bagian I dan II. Bandung Kaifa.

Ibrahim, M \& Nur, M. (2000). Pembelajaran Kooperatif. Surabaya Universiti Press.

Puskur-BalitBang Depdiknas. (2007). Kurikulum Tingkat Satuan Pendidikan (KTSP). Jakarta: Puskur-Balitbang

Silberman, M. (2004). Actife Learning. Yogyakarta: Yappendis.

Sardiman. (2005). Interaksi Dan Disiplin Belajar Siswa. Dj.Rajawali Press. Jakarta.

Mardalis. (2009). Metode Penelitian Suatu Pendekatan proposal. Bumi Aksara. Jakarta.

Sagala, Syaiful. (2007). Konsep Dan Makna Pembelajaran. CV. Alfabeta, Bandung.

Slameto. (2005). Belajar Dan Faktor-Faktor Yang Mempengaruhinya. PT Rineka Cipta. Jakarta.

Muhibbin. (2005). Psikologi Belajar. PT. Grafindo Persada, Jakarta. 
Margono. (2005). Metode Penelitian Pendidikan. PT. Rineka Cipta, Jakarta.

Surya, Muhammad. (2006). Psikologi Pembelajaran Dan Pengajaran. Pustaka Bani Quraisy. 